\title{
In situ human papillomavirus (HPV) genotyping of cervical intraepithelial neoplasia in South African and British patients: Evidence for putative HPV integration in vivo
}

University of Oxford, Nuffield Department of Pathology and

Bacteriology, John Radcliffe Hospital, Oxford OX3 9DU

K Cooper

C $S$ Herrington

A K Graham

M F Evans

J O'D McGee

Correspondence to: Professor J O'D McGee Accepted for publication 6 December 1990

\begin{abstract}
In South Africa asymptomatic wart virus infection diagnosed by morphological criteria occurs in $16-20 \%$ of all ethnic groups; the incidence in black women is $66 \%$. To identify human papillomavirus (HPV) types the prevalence of HPV in cervical intraepithelial neoplasia (CIN) in South African women $(n=72)$ with age matched British women $(n=73)$ was compared by non-isotopic in situ hybridisation (NISH) using digoxigenin labelled probes for HPV $6,11,16,18,31,33$ and 35 on archival biopsy specimens. A higher proportion of British biopsy specimens $(68 \%)$ contained HPV than those from South Africa (50\%) in CIN 2 and 3; this difference was due to HPV 16. Thirty six per cent of the positive biopsy specimens from South African women also contained HPV $33 / 35$ compared with $16 \%$ in the United Kingdom. There was no difference in HPV detection with age in either group. These data indicate that HPV types vary geographically, with "minor" HPV types being more common in South Africa. Three qualitatively distinct NISH signals were observed; a diffuse (type 1) signal in superficial cells, mainly koilocytes; a punctate signal (type 2) in basal/"undifferentiated" cells in CIN 3; and combined type 1 and 2 signals in CIN with wart virus infection (type 3). The punctate signal may represent HPV integration.
\end{abstract}

Over 60 types of human papillomavirus (HPV) have been described over the past decade, with HPV 6, 11, 42, 43, 44 associated predominantly with genital condylomata and low grade cervical dysplasia (cervical intraepithelial neoplasia (CIN 1-2)), and HPV 16,18 -and to a lesser extent, 31, 33, 35, 45, $51,52,56$, associated with high grade cervical dysplasia (CIN 3). ${ }^{12}$ Munoz et al summarised all hybridisation studies in women with CIN and cervical cancer (1983-1987) in whom the prevalence of HPV types $6,11,16$ or 18 had been reported. ${ }^{3}$ There was wide variation in prevalence within the same and among different countries. There are no data on the prevalence of HPV types in CIN in South Africa where cervical cancer is becoming increasingly common; nor have HPV 31, 33, and 35 been analysed in all grades of CIN in South Africa or the United Kingdom.

It has been contended that morphological criteria alone predict HPV 16 infection in severe grades of CIN associated with wart virus infection, ${ }^{45}$ specifically koilocytosis, which has been used as an absolute comparator for assessing sensitivity of hybridisation assays for HPV typing. ${ }^{6}$.

This paper addresses two questions: (i) the prevalence of HPV types in CIN 2 and 3, with and without evidence of wart virus infection, in South African and British patients; and (ii) do morphological criteria alone predict HPV infection or the infecting HPV type?

\section{Methods}

Archival, formalin fixed, paraffin wax embedded colposcopic cervical punch biopsy specimens of CIN ( $n=72$ ) were obtained at random for the year 1988 from the routine surgical files of the King Edward VIII Hospital, Durban, South Africa. An age matched group of biopsy specimens $(n=73)$ from the same year were similarly retrieved from the Oxford surgical files. All were colposcopic referrals for abnormal cervical smears. As control groups, 19 normal cervices from hysterectomy specimens removed for fibroids were obtained from the United Kingdom group, as well as 15 normal colposcopic cervical biopsy specimens from South African patients referred for inflammatory atypia.

Slides stained with haematoxylin and eosin from each of the biopsy specimens were reviewed and classified into three morphological groups according to the grade of CIN and the presence or absence of morphological evidence of wart virus infection by standard criteria. $^{7}$ In particular, the CIN $3+$ wart virus infection group was defined as fulfilling the criteria for CIN 3 and wart virus infection within the same segment of epithelium. There was no case of CIN 2 without wart virus infection. Biopsy specimens with CIN 1 or wart virus infection alone were not considered for the study; the morphological criteria for the differentiation of these two groups is controversial.

NISH

All chemicals were obtained from Sigma (UK) or BDH (UK) unless otherwise stated. 
Table 1 HPV typing in CIN in South African and British patients

\begin{tabular}{|c|c|c|c|c|c|c|c|c|c|c|c|c|c|c|c|}
\hline \multirow[b]{3}{*}{$\begin{array}{l}\text { Biopsy } \\
\text { diagnosis }\end{array}$} & \multirow{2}{*}{\multicolumn{2}{|c|}{ Cases examined }} & \multirow{2}{*}{\multicolumn{2}{|c|}{ Negative }} & \multicolumn{8}{|c|}{ HPV types } & \multirow{2}{*}{\multicolumn{2}{|c|}{ Total }} & \multirow[b]{3}{*}{$\chi^{2}$ test } \\
\hline & & & & & \multicolumn{2}{|l|}{16} & \multicolumn{2}{|l|}{18} & \multicolumn{2}{|l|}{33} & \multicolumn{2}{|l|}{35} & & & \\
\hline & $\begin{array}{l}\text { South } \\
\text { African }\end{array}$ & British & $\begin{array}{l}\text { South } \\
\text { African }\end{array}$ & British & $\begin{array}{l}\text { South } \\
\text { African }\end{array}$ & British & $\begin{array}{l}\text { South } \\
\text { African }\end{array}$ & British & $\begin{array}{l}\text { South } \\
\text { African }\end{array}$ & British & $\begin{array}{l}\text { South } \\
\text { African }\end{array}$ & British & $\begin{array}{l}\text { South } \\
\text { African }\end{array}$ & British & \\
\hline $\begin{array}{l}\text { CIN } 2+ \\
\text { wart virus } \\
\text { infection } \\
\text { CIN } 3+\end{array}$ & 17 & 24 & 8 & 10 & 1 & 10 & 1 & 1 & 5 & 1 & 2 & 2 & $9(53 \%)$ & $14(58 \%)$ & $\mathrm{p}>0.05$ \\
\hline $\begin{array}{l}\text { wart virus } \\
\text { infection } \\
\text { CIN } 3 \text { only } \\
\text { Total }\end{array}$ & $\begin{array}{l}32 \\
23 \\
72\end{array}$ & $\begin{array}{l}30 \\
19 \\
73\end{array}$ & $\begin{array}{r}19 \\
9 \\
36\end{array}$ & $\begin{array}{r}5 \\
8 \\
23\end{array}$ & $\begin{array}{c}8 \\
7 \\
16\end{array}$ & $\begin{array}{r}17 \\
7 \\
34\end{array}$ & $\begin{array}{l}1 \\
5 \\
7\end{array}$ & $\begin{array}{l}5 \\
2 \\
8\end{array}$ & $\begin{array}{l}1 \\
2 \\
8\end{array}$ & $\begin{array}{l}3 \\
0 \\
4\end{array}$ & $\begin{array}{l}3 \\
0 \\
5\end{array}$ & $\begin{array}{l}0 \\
2 \\
4\end{array}$ & $\begin{array}{l}13(41 \%) \\
14(61 \%) \\
36(50 \%)\end{array}$ & $\begin{array}{l}25(83 \%) \\
11(58 \%) \\
50(68 \%)\end{array}$ & $\begin{array}{l}p<0.01 \\
p>0.10 \\
p<0.05\end{array}$ \\
\hline
\end{tabular}

Probes

The HPV 6 probe consisted of the amp2 fragment of the viral genome cloned into pBR $322,{ }^{8}$ the HPV 11 probe, the whole viral genome in pBR322, ${ }^{9}$ the HPV 16 probe, the whole viral genome in pAT $153,{ }^{10}$ the HPV 18 probe, the whole viral genome in pBR322, ${ }^{11}$ the HPV 31 probe, the whole viral genome in pT713, ${ }^{12}$ the HPV 33 probe, the whole viral genome in pBR322 $22^{13}$ and the HPV 35 probe, the whole viral genome in pT713. ${ }^{14}$

Digoxigenin was incorporated into plasmid DNAs by nick translation as described previously. ${ }^{15}$ The nick translated fragments ranged from $50-1000$ base pairs with a median size of $200-400$ base pairs. $^{16}$

Unmasking of nucleic acids in biopsy specimens Paraffin wax sections were prepared as described previously ${ }^{17}$ and incubated in proteinase $\mathrm{K}$ (Boehringer, Germany) at a concentration of $500 \mu \mathrm{g} / \mathrm{ml}$ in $10 \mathrm{mM}$ phosphate, $100 \mathrm{mM} \mathrm{NaCl}, \mathrm{pH} 7 \cdot 2$ (PBS) for 15 minutes, washed thoroughly in distilled water followed by PBS and dried at $75^{\circ} \mathrm{C}$.

\section{Hybridisation}

Aliquots of hybridisation mix $(8 \mu \mathrm{l})$ containing $2 \mathrm{ng} / \mu \mathrm{l}$ of digoxigenin labelled HPV 6,11 , $16,18,31,33$ or 35 were added to each well on multispot slides which were covered with a $14 \mathrm{~mm}$ glass coverslip (Chance, UK) and the slides placed in a moist Terasaki plate. The

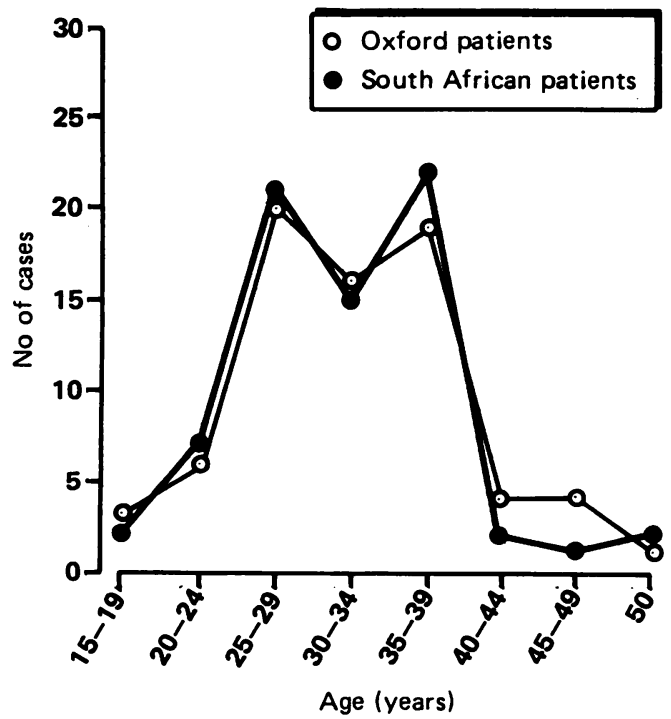

Figure 1 Comparative age distribution between South African and British groups. hybridisation mix and hybridisation conditions were as described previously. ${ }^{15}$

\section{Detection of hybridisation signal}

Detection was performed using a three step method as previously described. ${ }^{17}$ Briefly, slides were washed in three changes of $4 \times$ SSC at $22^{\circ} \mathrm{C}$ (five minutes each change), soaked in blocking agent TBT $(0.05 \mathrm{~mol} / 1$ TRIS- $\mathrm{HCl}, \quad 0.10 \mathrm{~mol} / \mathrm{l}$ sodium chloride (pH 7.2) containing 3\% (w/v) bovine serum albumin and $0.05 \%$ Triton-X $100(\mathrm{v} / \mathrm{v}))$ at $22^{\circ} \mathrm{C}$ for 10 minutes. Sections were incubated in monoclonal antidigoxin (Sigma UK) diluted 1 in 10000 in TBT for 30 minutes at $22^{\circ} \mathrm{C}$. A second incubation was in biotinylated rabbit anti-mouse $\left(\mathrm{F}\left(\mathrm{ab}^{\prime}\right)_{2}\right.$ fragment) (Dako, UK) diluted 1 in 200 in TBT and the third in avidin-peroxidase (Dako, UK) diluted 1 in 75 in TBT containing $5 \%(\mathrm{w} / \mathrm{v})$ non-fat milk. Signal was developed using aminoethylcarbazole (AEC) and hydrogen peroxide (Zymed, USA). After probe detection slides were air dried at $42^{\circ} \mathrm{C}$, counterstained progressively in haematoxylin, and mounted in glycerol jelly.

Distributions were compared with a two tailed $\chi^{2}$ test, using Yates' correction where applicable. The age distributions were compared using the Mann-Witney $U$ test.

\section{Results}

No signal was obtained with any of the HPV probes used in this study in the normal cervices from British patients $(n=19)$ or the South African group $(n=15)$.

\section{DISTRIBUTION OF HPV TYPES}

The overall HPV DNA detection rate in the South African (50\%) and British $(68 \%)$ groups (table 1$)$ was significantly different $(p<0.05)$.

Table 2 Comparative relation between age and HPV types

\begin{tabular}{|c|c|c|c|c|}
\hline \multirow[b]{3}{*}{ HPV types ${ }^{\star}$} & \multicolumn{4}{|l|}{ Age } \\
\hline & \multicolumn{2}{|l|}{$<30 y$} & \multicolumn{2}{|l|}{$>30 y$} \\
\hline & $\begin{array}{l}\text { South } \\
\text { African }\end{array}$ & British & $\begin{array}{l}\text { South } \\
\text { African }\end{array}$ & British \\
\hline $\begin{array}{l}16 \\
18 \\
33 \\
35 \\
\text { Negative }\end{array}$ & $\begin{array}{r}5 \\
3 \\
6 \\
2 \\
12\end{array}$ & $\begin{array}{r}14 \\
3 \\
3 \\
1 \\
7\end{array}$ & $\begin{array}{r}11 \\
4 \\
2 \\
3 \\
24\end{array}$ & $\begin{array}{r}20 \\
5 \\
1 \\
3 \\
16\end{array}$ \\
\hline
\end{tabular}

${ }^{\star}$ HPV $6,11,31$ were not present in any of the biopsy specimens. 


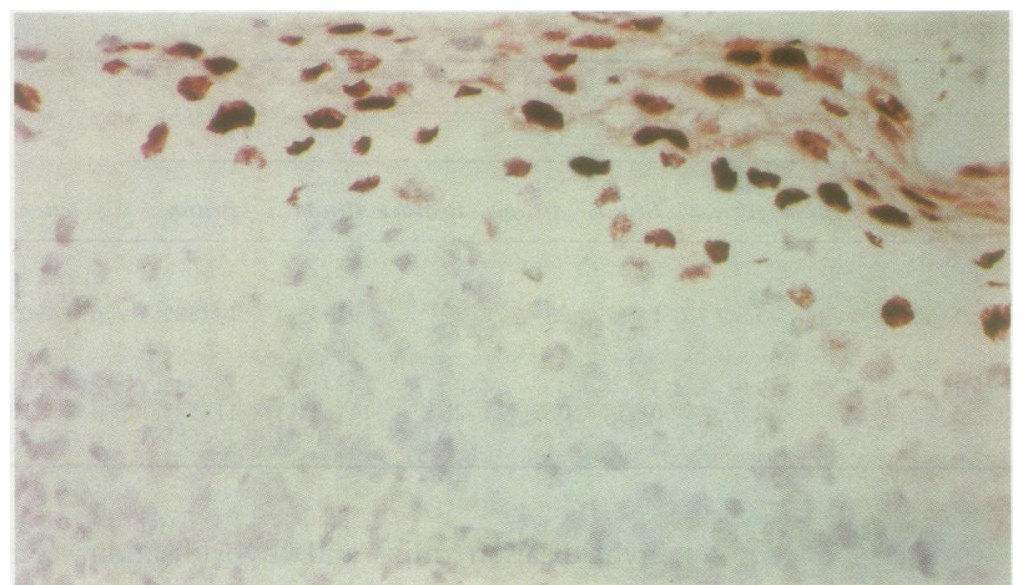

Figure 2 Type 1 pattern of red NISH signal confined to the upper half of the squamous epithelium.

In the cases positive for HPV HPV 16 predominated, with a prevalence of $68 \%$ and $44 \%$ in the British and South African series, respectively. This contrasted with a combined HPV $33 / 35$ detecting rate of $36 \%$ in CIN 2 and 3 in the positive cases in the South African series and $16 \%$ in the British group. There was no difference in the prevalence of HPV 18 between the two groups. HPV 6, 11, and 31 were not present in any of the cases.

\section{CORRELATION OF MORPHOLOGY WITH PRESENCE OF HPV TYPE (table 1)}

Taking all HPV types together, there was no difference between the South African and British groups in biopsy specimens showing CIN 2 with morphological evidence of wart virus infection and CIN 3 without wart virus infection. In contrast, a higher proportion of CIN 3 lesions with wart virus infection contained HPV sequences in the British group (83\%) compared with the South African group $(41 \%)$; this was significant $(p<0.01)$ and was due to the presence of HPV 16 in $57 \%$ of the British cases. Similarly, HPV 16 was found in a higher proportion of CIN 2 lesions with wart virus infection in the British group (42\%) compared with the South African group (6\%); but there was a higher HPV 33/35 infection

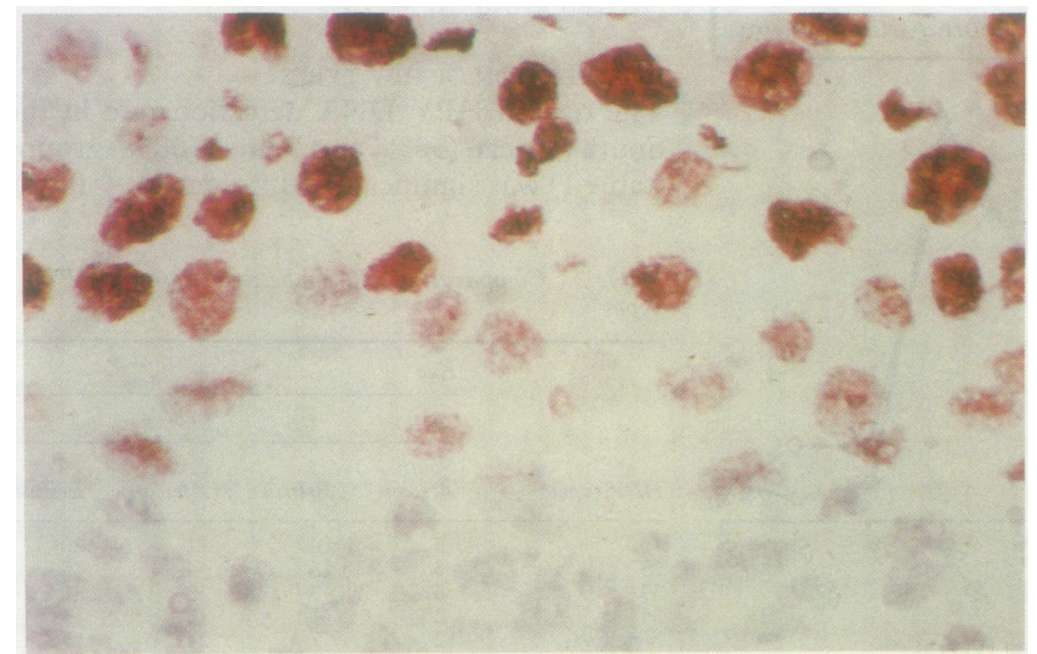

Figure 3 Diffuse red intranuclear signal present predominantly in cells showing morphological evidence of wart virus infection. rate of these lesions in the South African group (41\%) compared with the British group (13\%).

The prevalence of HPV 16 sequences increased in both the South African and British groups, with increasing severity of CIN irrespective of the presence or absence of morphological evidence of wart virus infection (British group with CIN 2, 42\%; CIN 3, 49\%: South African group with CIN 2, $6 \%$; CIN 3, $27 \%$ ). A similar trend was also present for HPV 18 (British group with CIN 2, 4\%; CIN 3, 14\%: South African group with CIN 2, $6 \%$; CIN 3, $11 \%$ ). The number of cases in each of these groups was not sufficiently large for statistical analysis.

Combining both groups, the rate of HPV positivity did not increase when there was morphological evidence of wart virus infection; CIN 2 and 3 with evidence of wart virus infection was $59 \cdot 2 \%$; CIN 3 without evidence of wart virus infection was $59 \cdot 5 \%$. Retrospective review of the morphological features of parallel haematoxylin and eosin stained sections of the NISH positive biopsy specimens did not show any distinctive features that could be used to predict the HPV type in any of the three morphological groups.

\section{CORRELATION BETWEEN AGE AND HPV DNA IN CIN}

A comparison of the South African and British groups by age is shown in fig 1 . There was no difference in the distribution as assessed by the Mann-Witney U test $(p=0 \cdot 24)$.

Separation of the two groups according to age (those under 30 and those aged 30 or more) did not show any statistical difference in the detection rate of HPV DNA (under 30, p $>0.1 ; 30$ and over, $p>0.05$ ) (table 2). Using the same age group divisions, no difference was noted within either nationality in terms of NISH positivity (South African group, $p>0 \cdot 1$ : British group, $p>0 \cdot 1)$. The combined overall detection rate of HPV 16 sequences was not significantly different between these two age groups $(p>0 \cdot 1)$.

\section{PATTERN OF NISH SIGNAL}

Although the location of HPV DNA in epithelia varied, two distinct patterns of signal were evident. In CIN 2 and 3 with morphological evidence of wart virus infection (either adjacent to or coincident with the CIN area) the signal was located predominantly in the superficial and intermediate layers of the squamous epithelium irrespective of the viral type (fig 2). This intranuclear signal was diffuse and granular: this is referred to as a type 1 signal (fig 3). Lesions with CIN 3 with no morphological evidence of wart virus infection were not associated with any specific location of signal within the epithelia. Rather, the signal was random in distribution and was present in basal and parabasal cells. This took the form of a distinct red punctate signal (dots) on a clean background of haematoxylin stained nuclei: this is referred to as type 2 signal (fig 4 ) and is similar to that observed earlier for CaSki cells which contain integrated HPV $16 .{ }^{17}$ Interestingly, this type of signal was also present in the 
Figure 4 Red punctate signal (dots) on a clean background of undifferentiated nuclei in a CIN 3 lesion (type 2) (haematoxylin)

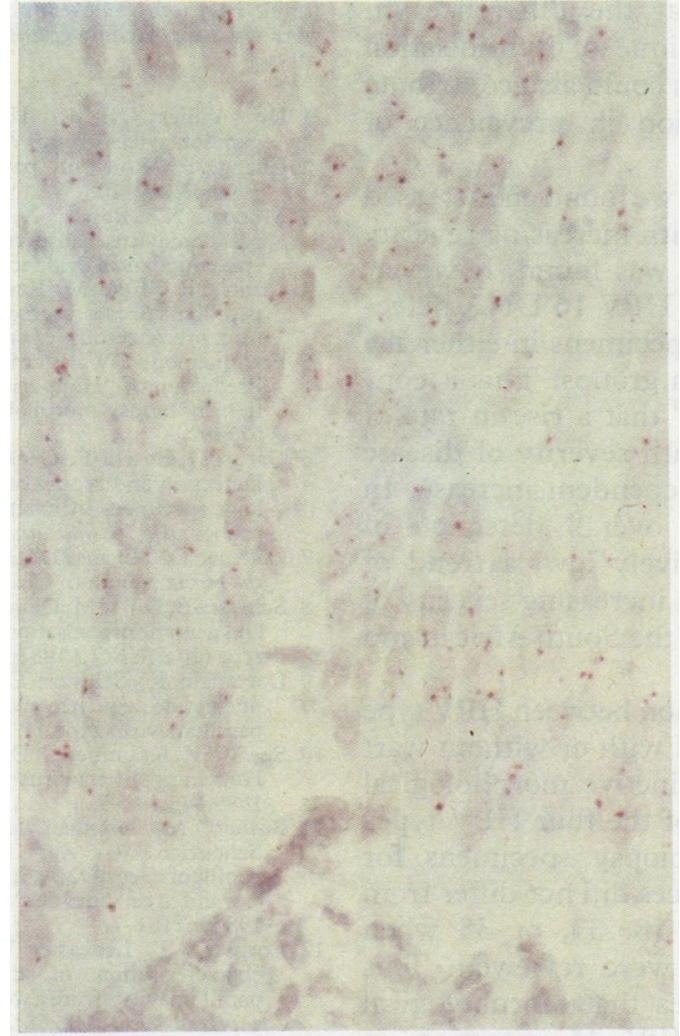

deeper layers of epithelia of some of the CIN 3 cases with wart virus infection (British group $56 \%$, South African group 50\%) which showed superficial type 1 signal. This combination of type 1 and 2 signal is referred to as type 3 (fig 5) and was present in the same cell, or separately in individual cells within the same lesion.

\section{Discussion}

In the South African screening programme morphological evidence of wart virus infection was present in 16-20\% of the population overall, irrespective of race $^{18}$; the incidence was higher $(66 \%)$ in black women. ${ }^{19}$ This study records the HPV types associated with CIN, with and without wart virus infection, in black

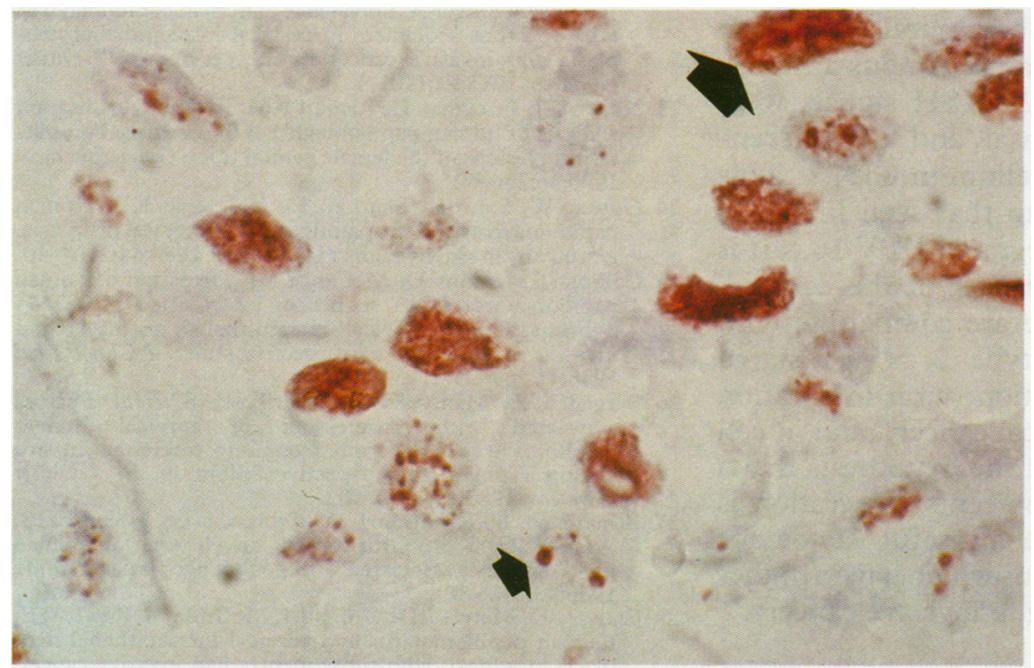

Figure 5 Combined type 1 (large arrow) and 2 (small arrow) staining in the same lesion (type 3) showing both CIN 3 and morphological evidence of wart virus infection. women. The combined incidence of all HPV types examined was $50 \%$ over the spectrum CIN 2-3 (with or without wart virus infection). In the virus positive cases HPV 16 was most prevalent $(44 \%)$, followed by HPV $33(22 \%)$, HPV $18(19 \%)$ and HPV $35(14 \%)$. HPV 6, 11, and 31 were not detected in any of the 72 CIN cases.

The higher prevalence of HPV DNA sequences in CIN in the British group (68\%) is similar to the detection rate of HPV in other western countries. ${ }^{35}$ These data confirm previous documentation of geographic variation in the prevalence of HPV infection between different areas in the United Kingdom, ${ }^{20}$ where it has been shown that the detection rate of HPV in CIN lesions ranges from $29.6 \%$ for combined 16 and $18^{21}$ to $62 \%$ for HPV $16^{22}$

In contrast to the British group, in which $68 \%$ of the HPV positive biopsy specimens contained HPV 16 , only $44 \%$ of the positive biopsy specimens from South African women contained this HPV type. This accounted for the difference in overall prevalence rates between the two groups. Thirty six per cent of the HPV positive biopsy specimens in the South African series, however, comprised HPV 33 and 35 compared with $16 \%$ in the British. These results indicate that the less common HPV types are relatively more frequent in South Africa. HPV sequences were also detected less frequently in CIN 3 with wart virus infection $(41 \%)$ compared with British cases $(83 \%)$. Assuming that the morphological criteria for wart virus infection are an absolute indicator of HPV infection, these data suggest that the South African cases contained HPV types not probed for in this study. Preliminary experiments indicate that this is probably so (K Cooper and J O'D McGee, unpublished observations).

The low detection rate of HPV 18 in CIN in both the HPV positive South African (19.4\%) and British (16\%) biopsy specimens is similar to that of other western studies. ${ }^{32324}$ The absence of HPV 6 and 11 in CIN 2 and 3 is not unusual and has been observed previously. ${ }^{5}$

In contrast to other countries, we found no cases of HPV 31 in the South African or British cases, but a $2 \%$ incidence in CIN has been recorded in London. ${ }^{25} \mathrm{HPV} 31$ has been found in $8.5 \%^{24}$ and $20 \%^{12}$ of cases of CIN in the USA. In Finland HPV 31 was present in five of $66(7 \cdot 5 \%)$ cervical HPV infections that progressed to CIN 3. ${ }^{26}$

HPV 33 was detected in $22 \cdot 2 \%$ and $8 \%$ of the positive biopsy specimens in the South African and British groups, respectively. HPV 33 was present in only two of 29 cases of CIN 3 in France ${ }^{27}$ and in $10.6 \%$ of Finnish cases. ${ }^{26}$ Using a HPV 16/33 cocktail, these sequences were found in $27 \%$ to $54 \%$ of CIN in Canada. ${ }^{28}$ HPV 35 was cloned from an endocervical adenocarcinoma and found to be present in two of 137 cases of $\mathrm{CIN}^{14}$ in 1987. This study from 1988 detected HPV 35 in $8 \%$ (Britain) and $13.8 \%$ (South Africa) of the positive biopsy specimens. Taken together these comparisons suggest that human papillomaviruses may vary geographically or with calendar year. It should 
be noted, however, that the differences in methodology and technique of hybridisation used in the above studies could also contribute to the apparent variation in prevalence of human papillomavirus. ${ }^{3}$

As in other studies, ${ }^{22}{ }^{28}$ we found an increased positivity for HPV 16 with increasing severity of CIN. No correlation was found, however, between age and rate of HPV 16 DNA detection in cervical biopsy specimens in either the South African or British groups. This is contrary to the suggestion ${ }^{29}$ that a rise in rate of detection of HPV 16 with severity of disease simply reflects an age dependent increase. In addition, although the overall detection of HPV 18 was comparatively low, a trend of increased positivity with increasing severity of CIN was evident in both the South African and British groups.

There was no correlation between HPV type and morphology of CIN with or without wart virus infection. No distinctive morphological features predicted any of the four HPV types found in this study: biopsy specimens for positive HPV 16 sequences did not differ from those containing HPV 18, 33, or 35 when morphological features were reviewed. This militates against the idea that morphological criteria can predict HPV 16 infection in cervical epithelia. ${ }^{45}$ Poor correlation between morphological characteristics and HPV type has also been reported by others. ${ }^{30}$ Garuti et al used koilocytosis as the absolute comparator for sensitivity of NISH and Southern blotting detection of HPV in genital biopsy specimens. ${ }^{6}$ The detection of HPV sequences in $60 \%$ of CIN 3 lesions without koilocytosis (or other evidence of wart virus infection) indicates that this approach to sensitivity measurements is invalid. Furthermore, from a diagnostic point of view the absence of koilocytosis does not exclude diagnosis of HPV infection; this is also true for cytologically normal and abnormal smears.

The three qualitatively different NISH signals observed here are noteworthy and may have pathobiological importance. The diffuse type 1 signal was found in superficial epithelial layers and in koilocytosis. This has a similar distribution to HPV capsid protein ${ }^{31}$ and probably represents episomal viral replication in permissive cells showing squamous differentiation. $^{2}$ Punctate type 2 NISH signals were detected in basal, parabasal, and "undifferentiated" cells in the epithelium in CIN 3. This signal type is identical to that seen in CaSki cells ${ }^{17}$ which contain integrated HPV $16 .^{32}$ It is also found in invasive cancer of the cervix. ${ }^{33}$ This and other evidence are compatible with the hypothesis that a type 2 NISH signal represents HPV integration; viral integration has been shown in cervical cancer ${ }^{35}$ and in cell lines derived from it. ${ }^{32}$ If the hypothesis that a type $2 \mathrm{NISH}$ signal represents integration is correct this may prove a useful factor for differentiating CIN lesions which have a higher likelihood of progressing to invasive cancers.

$\mathrm{K} \mathrm{C}$ is an Oxford Nuffield Medical Fellow. $\mathrm{C} \mathrm{S} \mathrm{H}$ is a Cancer Research Campaign, Clinical Research Fellow and holds a
Junior Research Fellowship at Green College, Oxford. This work was supported by grants from the CRC to J O'D McG.

1 De Villiers E-M. Heterogeneity of the human papillomavirus group. J Virol 1989;63:4898-903.

2 Chang F. Role of papillomaviruses. J Clin Pathol 1990;43:269-76.

3 Munoz N, Bosch X, Kaldor JM. Does human papillomavirus cause cervical cancer? The state of the epidemiological evidence. Br J Cancer 1988;57:1-5.

4 Crum CP, Mitao M, Levine RU, Silverstein S. Cervical papillomaviruses segregate within morphologically dispapillomaviruses segregate within morphologically
tinct precancerous lesions. $J$ Virol $1985 ; 54: 675-81$.

5 Franquemont DW, Ward BE, Anderson WA, Crum CP. Prediction of "High-risk" cervical papillomavirus infection by biopsy morphology. Am J Clin Pathol 1989;92. $577-82$.

6 Garuti G, Boselli F, Genazzani AR, Silverstri S, Ratti G. Detection and typing of human papillomavirus in histologic specimens by in situ hybridisation with biotinylated probes. Am J Clin Pathol 1989;92:604-12.

7 Coleman DV, Evans DMD. Bilopsy pathology and cytology of the cervix. London: Chapman and Hall, 1988:199-227.

8 Schwarz E, Dürst M, Demankowski C, et al. DNA sequence and genome organisation of genital human papillomavirus and genome organisation of genita

9 Dartmann K, Schwarz E, Gissman Zur Hausen H. The nucleotide sequence and genome organisation of human pacleotide sequence and genome organisation of

10 Seedorf K, Krämmer G, Dürst M, Suhai S, Röwekamp WG Human papillomavirus type 16 DNA sequence. Virology 1985;145:181-5.

11 Boshart M, Gissman L, Ikenberg $H$, Kleinheinz A Scheurlen W, Zur Hausen H. A new type of papillomavirus DNA, its presence in genital cancer biopsies and in cell lines derived from cervical cancer. $E M B O J$ 1984;3:1151-7.

12 Lorincz AT, Lancaster WD, Temple GF. Cloning and characterisation of the DNA of a new human papillomavirus from a woman with dysplasia of the uterine papillomavirus from a woman with

13 Cole ST, Streeck RE. Genome organisation and nucleotide sequence of human papillomavirus type 33, which is associated with cervical cancer. $J$ Virol 1986;58:991-5.

14 Lorincz AT, Quinn AP, Lancaster WD, Temple GP. A new papillomavirus associated with cancer of the uterine cervix. Virology 1987;159:187-90.

15 Herrington CS, Burns J, Graham AK, Bhatt B, McGee JO'D. Interphase Cytogenetics using biotin and digoxigenin labelled probes I: relative sensitivity of both reporter molecules for the detection of HPV 16 in CaSki cells. J Clin Pathol 1989;42:591-600.

16 Chan VT-W, Fleming KA, McGee JO'D. Detection of subpicogram quantities of specific DNA sequences on blot hubpicogram quantities of specific DNA sequences on blot 1985;13:8083-91.

17 Herrington CS, Graham AK, McGee JO'D. Interphase Cytogenetics III: Increased sensitivity and flexibility of digoxigenin labelled DNA probes for HPV detection in cervical biopsies and cell lines. J Clin Pathol 1991;44:33-8.

18 Bloch B. Sexually transmitted diseases and cancer. Med Sex J 1989;2:42-4.

19 Markowitz S, Leiman G, Margolis KA. Human papillomavirus and cervical intraepthelial neoplasia in an
African population. $S$ Afr J Epidemiol Infect 1986;1:65-9.

20 Jenkins D, Tay SK, Dyson JL. Koilocyte frequency and prevalence of cervical human papillomavirus infection. prevalence of cervical
Lancet 1986;1:557-8.

21 Toon PG, Arrand JR, Wilson LP, Sharp DS. Human papillomavirus infection of the uterine cervix of women papillomavirus infection of the uterine cervix of women
without cytological signs of neoplasia. $B r$ Med $J$ without cytological

22 McCance DJ, Campion MJ, Clarkson PK, Chester PM, Jenkins D, Singer A. Prevalence of human papillomavirus type 16 DNA sequences in cervical intraepithelial neoplasia and invasive cancer of the cervix. Br J Obste Gynaecol 1985;92:1101-5.

23 Nuovo GJ, Friedman D, Richart RM. In situ hybridisation analysis of human papillomavirus DNA segregation patterns in lesions of the female genital tract. Gynaecol Oncol 1990;36:256-62.

24 Gupta JW, Saito K, Saito A, Fu YS, Shah KV. Human papillomavirus and the pathogenesis of cervical neoplasia. papillomavirus and the pathogenesis of cervical neoplasia. A study by in situ hybridisation. Cancer 1989;64:2104-10.
Collins JE, Jenkins D, McCance DJ. Detection of human Collins JE, Jenkins D, McCance DJ. Detection of human
papillomavirus DNA sequences by in situ DNA-DNA papillomavirus DNA sequences by in situ DNA-DNA
hybridisation in cervical intraepithelial neoplasia and hybridisation in cervical intraepithelial neoplasia and
invasive carcinoma: a retrospective study. J Clin Pathol invasive carcinom

26 Syrgänen K, Mäntyjärvi R, Saarikoski S, et al. Factors associated with progression of cervical human papillomavirus (HPV) infections into carcinoma in situ during a long-term prospective follow up. $\mathrm{Br} J$ Obste Gynaecol 1988;95:1096-102.

27 Beaudenon S, Kremsdorf D, Croissant O, Jablonska S, Wain-Hobson $S$, Orth $G$. A novel type of human papillomavirus associated with genital neoplasias. Nature 1986;321:426-8.

28 Caussey D, Marret LD, Worth AJ, McBride M, Rawls WE. Human papillomavirus and cervical intraepithelial neoplasia in woman who subsequently had invasive cancer. Can Med Assoc J 1990;142:311-17.

29 Meanwell CA, Cox MF, Blackledge G, Maitland NJ. HPV 
16 DNA in normal and malignant cervical epithelium: Implications for the aetiology and behaviour of cervical

neoplasia. Lancet 1987;i:703-7.
30 Kadish AS, Burk RD, Kress Y, Calderin S, Romney SL. Human papillomavirus of different types in precancerous Human papillomavirus of different types in precancerous lesions of the uterine cervix: histologic, immunocytochemical and

31 Graham AK, Herrington CS, McGee JO'D. Sensitivity and specificity of monoclonal antibodies to human papillomavirus type 16 capsid protein: Comparison with simultaneous viral detection by non isotopic hybridisa- tion. J Clin Pathol 1991;44:96-101.

32 Mincheva A, Gissman L, Zur Hausen H. Chromosomal integration sites of human papillomavirus DNA in three cervical cancer cell lines mapped by in situ hybridisation. Med Microbiol Immunol 1987;176:245-56.

33 Cod Microbiol Immunol 1987;176:245-56. Cooper K, Herrington CS, Evans MF, Graham AK, McGee
JO'D. In situ evidence for HPV 16, 18, 33 integration in cervical squamous cell cancer in Britain and South Africa. cervical squamous cell cancer in

34 Dürst M, Kleinheinz A, Holtz M, Gissman L. The physical state of HPV type 16 DNA in benign and malignant genital tumours. J Gen Virol 1985;66:1515-22. 